Vol. 5 (1996): 521-527.

\title{
Production of calves following nonsurgical transfer of fresh and refrigerated bovine demi-embryos
}

\author{
Peter Bredbacka' \\ Agricultural Research Centre of Finland, Institute of Animal Production, FIN-31600 Jokioinen, Finland \\ Ülle Jaakma and Ilmar Müürsepp \\ Estonian Agricultural University, EE-2400 Tartu, Estonia
}

\begin{abstract}
The viability of microblade-bisected Day-7 embryos transferred to recipients without zona pellucidae directly after splitting or after overnight storage at $4^{\circ} \mathrm{C}$ was investigated in two experiments. In Experiment 1,26 demi-embryos of excellent or good quality and two of fair quality were transferred to 28 heifer recipients $1-3 \mathrm{~h}$ after splitting. The transfers resulted in 20 pregnancies ( $71.4 \%$ pregnancy rate), and 19 calves were born (one pregnant heifer was slaughtered). Another 14 demi-embryos were cultured 1 to $3 \mathrm{~h}$ at room temperature, transported for $3 \mathrm{~h}$ at $8-10^{\circ} \mathrm{C}$ and stored for $12 \mathrm{~h}$ in a refigerator at $4^{\circ} \mathrm{C}$. Twelve of the 14 demi-embryos were considered transferable after storage and nine of these were transferred to nine recipients, of which five became pregnant. Four live calves were born.

In Experiment 2, 21 excellent or good quality demi-embryos were transferred into 21 heifer recipients to produce 12 pregnancies $(57.1 \%)$ and 10 live calves. Another 19 demi-embryos (17 excellent to good quality and two fair quality) were transferred after storage for $1-2 \mathrm{~h}$ at $8^{\circ} \mathrm{C}$ and $18 \mathrm{~h}$ at $4^{\circ} \mathrm{C}$. Five recipients became pregnant, of which four delivered live calves.

It is concluded that a high pregnancy rate can be achieved after the transfer of fresh demi-embryos produced by a simple method of embryo bisection under farm conditions. Although the transfer of demi-embryos stored overnight at $4^{\circ} \mathrm{C}$ results in decreased pregnancy rates, refrigeration of demiembryos may be useful in certain practical situations. However, further experiments are needed to determine the optimal conditions for overnight storage of demi-embryos.
\end{abstract}

Key words: splitting, bisection, cold storage, embryo transfer, pregnancy rate

'Present address: Finnish Animal Breeding Association, P.O. Box 40, FIN-01301 Vantaa, Finland. e-mail: peter.bredbacka@mloy.fi

\section{Introduction}

The number of calves from valuable donors can be increased and genetically identical twins produced by bisecting cattle embryos. The success of the microsurgical methods used is based on the capability of the bovine demi-embryo to develop and form a calf after transfer into the uteri of recipients (Ozil et al. 1982). In recent years, attention has been paid to the development of rapid and simple splitting techniques reliable

(ㄷ) Agricultural and Food Science in Finland

Manuscript received August 1996 


\section{AGRICULTURAL AND FOOD SCIENCE IN FINLAND}

\section{Bredbacka, P. et al. Viability of fresh and refrigerated demi-embryos}

enough to allow wide use in commercial embryo transfer (ET) (Williams and Moore 1988, Bredbacka et al. 1995).

The highest pregnancy rates following transfer of demi-embryos have been achieved after splitting Day 7 embryos at the late morula and early blastocyst stages (Williams et al. 1984) with the survival rate being similar to or only slightly lower than that following transfer of fresh whole embryos (Leibo and Rall 1987, Williams and Moore 1988, Seike et al. 1989). The large volume of published data on demi-embryo survival after non-surgical single transfers suggests that about half of the transfers result in pregnancy. Since many discouraging results have probably remained unpublished, this may be an overestimate. Survival rates as high as $72.9 \%$ have been reported for a large number of transfers (Seike et al. 1989). A combination of freezing and thawing with splitting has, however, resulted in poorer in vitro survival (Rorie et al. 1986, Takeda et al. 1987) and relatively low pregnancy rates (Heyman and Chesné 1984, Schmidt et al. 1992). Overnight storage of bisected embryos without freezing would allow transport of excess demi-embryos to other locations for transfer, an alternative that has not received much attention. With intact embryos, nine of 19 transfers of embryos refrigerated for $24 \mathrm{~h}$ resulted in pregnancies and seven of 21 recipients became pregnant following transfer of embryos refrigerated for $48 \mathrm{~h}$ (Jaakma and Müürsepp 1991).

The purpose of our study was to investigate the viability of demi-embryos bisected on a farm with a rapid method using a microblade and transferred to recipients directly after splitting or after overnight storage at $4^{\circ} \mathrm{C}$.

\section{Material and methods}

\section{Embryo recovery}

Two experiments were set up on Aravete farm in Estonia. Donor cows were treated first with
FSH-P (Schering Co.,USA) or Follitropin (Kaunas, Lithuania) and then with cloprostenol (Oestrophan, Czechoslovakia) to induce superovulation. Seven days after artificial insemination embryos were recovered using standard nonsurgical procedures. The uterine horns were flushed with Dulbecco's phosphate buffered saline (Jurievets, Russia) containing 1\% foetal calf serum (Polva, Estonia). The embryos were collected from the flushing medium, rinsed several times and held in Dulbecco's phosphate buffered saline with $20 \%$ foetal calf serum (PBS+FCS) at room temperature $\left(24-26^{\circ} \mathrm{C}\right)$. The same medium was used for bisection and storage up to transfer. Antibiotics were not added.

\section{Embryo microsurgery}

The embryos were classified using the criteria of Lindner and Wright (1983). Late morulae, and early and late blastocysts of excellent (Grade 1) or good (Grade 2) quality were selected for splitting. One hydraulic micromanipulator (Narishige, Japan) and a microblade made of a razor blade (Williams and Moore 1988) were used in conjunction with a Leitz Diavert microscope. Each embryo was placed in a drop of medium on a plastic petri dish and fixed between the microblade and scratches made on the bottom of the dish with the microblade (Bredbacka 1991) to prevent the embryo from slipping during bisection. The embryos were cut into halves of equal size by pressing the blade vertically to the bottom of the dish. Blastocysts were bisected so that both the trophectoderm and the inner cell mass were halved. The bisections were completed at intervals of about 5 minutes. All demi-embryos were stored and transferred without a surrounding zona pellucida.

\section{Transfer of fresh demi-embryos}

In both experiments, each demi-embryo was nonsurgically transferred into the uterine horn ipsilateral to the corpus luteum of a heifer recipient 
Vol. 5 (1996): 521-527.

Table 1. Summary of bisection and single transfer of fresh or refrigerated demi-embryos.

\begin{tabular}{|c|c|c|c|c|c|c|c|}
\hline & \multicolumn{3}{|c|}{$\begin{array}{l}\text { No. of demi-embryos } \\
\text { Grade before transfer }\end{array}$} & \multicolumn{2}{|c|}{$\begin{array}{c}\text { Pregnant/transfer } \\
\text { Grade before transfer }\end{array}$} & \multicolumn{2}{|c|}{$\begin{array}{l}\text { Calves born/transfer } \\
\text { Grade before transfer }\end{array}$} \\
\hline & $1+2$ & 3 & 4 & $1+2$ & 3 & $1+2$ & 3 \\
\hline \multicolumn{8}{|l|}{ Experiment $1^{b}$} \\
\hline Fresh & 26 & 2 & - & $19 / 26$ & $1 / 2$ & $18 / 25^{\mathrm{c}}$ & $1 / 2$ \\
\hline Refrigerated & 8 & 4 & 2 & $4 / 7$ & $1 / 2$ & $3 / 7^{d}$ & $1 / 2$ \\
\hline \multicolumn{8}{|l|}{ Experiment $2^{\mathrm{b}}$} \\
\hline Fresh & 21 & - & - & $12 / 21$ & - & $10 / 21$ & - \\
\hline Refrigerated & 17 & 2 & - & $5 / 17$ & $0 / 2$ & $4 / 17$ & $0 / 2$ \\
\hline \multicolumn{8}{|l|}{ Total } \\
\hline Fresh & 47 & 2 & - & $31 / 47$ & $1 / 2$ & $28 / 46$ & $1 / 2$ \\
\hline Refrigerated & 25 & 6 & 2 & $9 / 24$ & $1 / 4$ & $7 / 24$ & $1 / 4$ \\
\hline
\end{tabular}

arade 1 = excellent quality, Grade 2 = good quality, Grade 3 = fair quality, Grade 4 = poor quality (not transferable).

${ }^{b}$ Experiment 1 was carried out in November and the refrigerated embryos were stored for 17-18 h.

Experiment 2 was performed in April and the refrigerated embryos were stored for 22-24 h.

' One pregnant heifer was slaughtered, (one of the 18 born died after a few days).

${ }^{d}$ One of the four calves was stillborn.

syncronized with cloprostenol after 1 to 3 hours of culture in PBS+FCS at room temperature. All recipients were checked for the corpus luteum (CL) on the day of transfer; those without CL or with poor quality $\mathrm{CL}$ were excluded. The time elapsing between flushing the donors and transfer to recipients was 5.5-6.5 h. All splitting and transfer procedures were performed on the farm.

\section{Transfer of refrigerated demi-embryos}

In Experiment 1, some of the demi-embryos were cultured for 1 to $3 \mathrm{~h}$ in PBS+FCS at room temperature and then drawn into plastic straws $(0.25$ ml transparent semen straws, I.M.V., L'Aigle, France) in PBS+FCS. The straws were placed in a box and transported for $3 \mathrm{~h}$ at $8-10^{\circ} \mathrm{C}$ to the laboratory in Tartu, where they were stored in a refrigerator for $12 \mathrm{~h}$ at $4^{\circ} \mathrm{C}$. The demi- embryos were then examined morphologically under a microscope and graded as above (neglecting the loss of half of the embryo due to bisection). A selection of demi-embryos appearing viable was transferred to recipients as described above. The total storage time after splitting was $17-18 \mathrm{~h}$.
In Experiment 2, some demi-embryos were kept for $1-2 \mathrm{~h}$ at $8-10^{\circ} \mathrm{C}$ in PBS+FCS in plastic straws, followed by $18 \mathrm{~h}$ storage in PBS+FCS at $4^{\circ} \mathrm{C}$. The demi-embryos were evaluated and transferred as in Experiment 1. The total storage time after splitting was $22-24 \mathrm{~h}$.

\section{Results}

\section{Experiment I}

The results of Experiment 1 are summarized in Table 1. Thirty-five embryos, among them 23 $(65.7 \%)$ of excellent or good quality compacted morulae or blastocysts were recovered. All excellent and good quality embryos were bisected. After bisection, 42 of 46 demi-embryos were of excellent or good quality and four were assessed as fair.

Twenty-eight demi-embryos, of which 26 were of excellent or good quality, were transferred to 28 recipients. These demi-embryos originated from 14 embryos, of which two were 


\section{AGRICULTURAL AND FOOD SCIENCE IN FINLAND}

Bredbacka, P. et al. Viability of fresh and refrigerated demi-embryos

late morulae, 10 early blastocysts and two late blastocysts. Twenty of the transfers resulted in pregnancy as estimated by palpation per rectum 60 days after transfer, which constitutes $71.4 \%$ of the demi-embryos transferred. One pregnant heifer was slaughtered, and 19 calves were born ( $70.4 \%$ calving rate). Both halves of the embryo resulted in pregnancy on five occasions and five pairs of monozygotic twins were delivered (35.7\% twinning efficiency).

Fourteen demi-embryos were stored overnight. One demi-embryo pair was unequally bisected and graded as fair; the remaining 12 were split into demi-embryos of equal size. Of these, five were considered of excellent quality and seven of good quality before storage. After storage, the morphological quality of these 12 demiembryos had declined, eight being assessed as good and four as fair. The two demi-embryos evaluated after splitting as fair were not considered viable after storage. Within 2 h of evaluation, nine of the demi-embryos considered viable (seven good quality and two fair quality) were transferred to nine recipients. Of these, four of the seven receiving good quality demi-embryos and one of the two receiving demi-embryos of fair quality became pregnant. Three refrigerated embryos (one of good quality and two of fair quality) were not transferred. The overall pregnancy rate resulting from the transfer of demi-embryos stored as described above was $55.6 \%$. Four live calves were produced from seven original embryos ( 0.57 calves per original embryo); one calf was stillborn.

\section{Experiment 2}

The results of Experiment 2 are summarized in Table 1. Twenty-two excellent or good quality embryos were bisected from a total of $24 \mathrm{em}-$ bryos to produce 44 demi-embryos. Of these, two were excluded because of unequal splitting and two due to a marked loss of quality. Thirty-eight of the remaining demi-embryos were of excellent or good quality and two were considered fair. Twelve pregnancies were established after trans- fer of 21 fresh, excellent to good quality demiembryos (57.1\% pregnancy rate). Ten calves were born ( $47.6 \%$ calving rate).

Nineteen demi-embryos were refrigerated overnight, seven of them of excellent quality, 10 of good quality and two of fair quality. No morphological changes were observed after storage. Five of the 17 recipients receiving an excellent or good quality demi-embryo became pregnant. Neither of the two heifers receiving demi-embryos assessed as fair prior to refrigeration established pregnancy. Four of the 19 heifers receiving a refrigerated demi-embryo produced a calf. Five sets of identical twins were born, one of them originating from a pair of refrigerated demi-embryos.

Combining the results of both experiments yields an overall pregnancy rate of $35.7 \%$ for refrigerated demi-embryos, which is significantly lower than the $65.3 \%$ pregnancy rate achieved with the transfer of fresh demi-embryos $(\mathrm{P}=0.01$, $\chi^{2}$-test).

\section{Discussion}

The data reported here demonstrate that simple and rapid embryo splitting with a microblade can be used to produce a high proportion of viable demi-embryos under farm conditions. Demiembryos received with this method and transferred directly to recipients resulted in a high pregnancy rate $(65.3 \%$ overall). During the last 3 years the pregnancy rate after transfer of fresh whole embryos on the same farm by the same technicians has been $74.3 \%$ (105 heifer recipients) which is not significantly higher $(\mathrm{P}=0.25$, $\chi^{2}$-test) than the pregnancy rate for fresh demiembryos acieved in this study. The number of transfers was, however, too small to permit conclusions to be drawn about the viability of demiembryos derived from embryos at different developmental stages.

Some data are available confirming that storage of whole fresh cow embryos at $4-5^{\circ} \mathrm{C}$ for up 


\section{AGRICULTURAL AND FOOD SCIENCE IN FINLAND}

\section{Vol. 5 (1996): 521-527.}

to 48 hours does not significantly impair their ability to develop (Trounson et al. 1976, BonDurant et al. 1982, Lindner and Ellis 1985). We have not, however, been able to obtain any data on the effect of storage of demi-embryos at low plus temperatures. Our results demonstrate a decrease in the viability of demi-embryos after overnight refrigeration. Twenty-eight of 33 refrigerated demi-embryos were transferred; 10 recipients became pregnant and eight calves were born.

The pregnancy rates in Experiment 1 were somewhat higher than those in Experiment 2. Although the difference was not significant $\left(\mathrm{P}=0.3, \chi^{2}\right.$-test $)$, seasonal factors may have contributed to the decrease in fertility. Experiment 1 was carried out in September and Experiment 2 in April. According to field data on transfers conducted by the same team as in this study, the pregnancy results obtained with Grade 1 to 2 embryos in April-June were similar to those obtained in autumn and winter $(67.3 \%, \mathrm{n}=101 \mathrm{vs}$. $64.5 \%, \mathrm{n}=402$ ). Transfer of Grade 3 embryos, however, yielded a lower pregnancy rate $\left(\mathrm{P}=0.05, \chi^{2}\right.$-test $)$ in April-June $(34.5 \%, \mathrm{n}=55)$ than in autumn and winter $(50.5 \%, \mathrm{n}=111)$. As bisection reduces embryo quality by definition (loss of cell mass), seasonal effects may have caused the lower pregnancy rate in Experiment 2. Moreover, the nutritional status of the animals was considered poorer in Experiment 2. Donor effects (Niemann 1991, Jaakma and Müürsepp 1991) may have further contributed to the difference between experiments. For instance, in Experiment 2, all five pregnancies from refrigerated embryos resulted from transfer of embryos from one donor, whereas none of the five transfers of demi-embryos from another donor established pregnancy.

Clearly, the pregnancy rates achieved by transferring cold-stored demi-embryos do not encourage embryo transfer practitioners to increase the flexibility of their working routines by refrigerating demi-embryos as a standard procedure. However, given the only moderate loss of viability in freshly transferred demi-embryos compared with that in intact embryos one should not overlook the feasibility of transferring one demi-embryo directly and the other half on another location on the following day. For instance, if two ET programmes were implemented 1 to 2 days apart and the embryo donors in the latter ET programme failed to respond to hormonal treatments, some of the demi-embryos bisected on the previous day in the first ET programme could be transported at $4{ }^{\circ} \mathrm{C}$ for transfer into synchronized recipients of the second programme. The pregnancy rate in the previous ET programme would be only marginally lower than that with transfer of intact embryos, but still some of the recipients in the latter ET programme would become pregnant.

Another way of utilizing overnight refrigeration of micromanipulated embryos would be to send embryo biopsies to a laboratory for preimplantation diagnosis. The refrigerated embryos could then be transferred as soon as the results of the assay were available. Since biopsy of only a few cells is required for genetic analysis, biopsied embryos would be expected to have survival rates between to those for intact and demiembryos.

If demi-embryos have to be stored at $+4^{\circ} \mathrm{C}$ before transfer, it may be advisable to use only excellent quality embryos for bisection, i.e. embryos with no visible defects. In Experiment 2 (which yielded the lower pregnancy rates), 16 of the original embryos were considered excellent. One of the splittings was unequal and two demi-embryos were therefore not transferred. Fourteen of the remaining 30 demi-embryos were transferred as fresh and 16 after refrigeration. Calving rates were $64 \%$ and $31 \%$ respectively, thus yielding 0.95 calves per original embryo (excluding the unequally bisected embryo). Such success should encourage further investigation into the feasibility of refrigerating one of two demi-embryos.

It is not enough to consider embryo quality alone, however; attention should also be paid to storage media and refrigeration temperatures. Furthermore, although our results confirm previous reports that the zona pellucida is not required for survival of Day-7 bovine demi-em- 


\section{AGRICULTURAL AND FOOD SCIENCE IN FINLAND}

Bredbacka, P. et al. Viability of fresh and refrigerated demi-embryos

bryos (e.g. Seike et al. 1989, McEvoy and Sreenan 1990), lack of the zona pellucida may impair the viability of refrigerated demi-embryos.

We conclude that pregnancy rates after transfer of zona-free demi-embryos produced by splitting Day-7 bovine embryos with a simple and rapid technique are, under ideal conditions, comparable to the results achieved by transfering fresh embryos. Overnight storage of demi-embryos in a refrigerator resulted in lower pregnancy rates. Nevertheless, refrigeration of demi- embryos may be useful in certain situations, at least once storage conditions of demi-embryos have been improved.

Acknowledgements. The authors thank the following persons for their technical assistance: Toomas Raaper from Aravete farm, Aavo Kallas, Jaak Samarütel, Sirje Pähn, Riina Tògo and Urve Laidvee from the Estonian Agricultural University and Mirja Huhtinen from the Agricultural Research Centre of Finland. We also thank Kristiina Bredbacka for valuable suggestions with regard to the manuscript.

\section{References}

BonDurant, R.H., Anderson, G.B., Boland, M.P., Cupps, P.T. \& Hughes, M.A. 1982. Preliminary studies on bovine embryo survival following short-term storage at $4^{\circ} \mathrm{C}$. Theriogenology $17: 223-230$.

Bredbacka, P. 1991. Biopsy of morulae and blastocysts. Reproduction in Domestic Animals 26: 82-84.

- , Kankaanpää, A. \& Peippo, J. 1995. PCR-sexing of bovine embryos: A simplified protocol. Theriogenology 44: 167-176.

Heyman, Y. \& Chesné, P. 1984. Freezing bovine embryos: survival after cervical transfer of one half, one or two blastocysts frozen in straws. Theriogenology 21: 240. (Abstract.)

Jaakma, Ü. \& Müürsepp, I. 1991. Retsipientide tiinestumine 24 või 48 tundi $4^{\circ} \mathrm{C}$ juures sälitatud embrüote siirdamise järel. Agraarteadus 2: 186-190.

Leibo, S.P. \& Rall, W.F. 1987. Increase in production of pregnancies by bisection of bovine embryos. Theriogenology 27: 245. Abstract.

Lindner, G.M. \& Ellis, D.E. 1985. Refrigeration of bovine embryos. Theriogenology 23: 202. (Abstract.)

- \& Wright, R.W. Jr. 1983. Bovine embryo morphology and evaluation. Theriogenology 20: 407-416.

McEvoy, T.G. \& Sreenan, J.M. 1990. Effect of embryo quality and stage of development on the survival of zona pellucida-free cattle demi-embryos. Theriogenology 33 : 1245-1253.

Niemann, H. 1991. Cryopreservation of ova and embry- os from livestock: Current status and research needs. Theriogenology 35: 109-124.

Ozil, J.P., Heyman, Y. \& Renard, J.P. 1982. Production of monozygotic twins by micromanipulation and cervical transfer in the cow. Veterinary Record 110: 126-127.

Rorie, R.W., Pendleton, R.J., Youngs, C.R. \& Godke R.A. 1986. Viability of demi-embryos produced before vs. after deep freezing. Theriogenology 25: 192. (Abstract.)

Schmidt, M., Smith, S.D., Avery, B., Purwantara, B. \& Greve, T. 1992. Coculture of Bovine Demiembryos Prior to Freezing. Acta Veterinaria Scandinavica 33: 237-243. Seike, N., Saeki, K., Utaka, K. Sakai, M., Takakura, R., Nagao, Y. \& Kanagawa, H. 1989. Production of bovine identical twins via transfer of demi-embryos without zonae pellucidae. Theriogenology 32: 211-220.

Takeda, T., Henderson, B.W. \& Hasler, J.F. 1987. Deep freezing of split and intact bovine embryos. Theriogenology 27: 285. (Abstract. )

Trounson, A.O., Willadsen, S.M. \& Rowson, L.E.A. 1976. The influence of in vitro culture and cooling on the survival and development of cow embryos. Journal of Reproduction and Fertility 47: 367-370.

Williams, T.J., Elsden, R.P. \& Seidel, G.E., Jr. 1984. Effect of embryo age and stage on pregnancy rates from demi-embryos. Theriogenology 21: 276. (Abstract.)

- \& Moore, L. 1988. Quick-splitting of bovine embryos. Theriogenology 29: 477-484. 
Vol. 5 (1996): 521-527.

\title{
SELOSTUS
}

\section{Vasikoiden tuottaminen tuoreilla ja kylmäsäilytetyillä halkaistuilla alkioilla}

\author{
Peter Bredbacka, Ülle Jaakma ja Ilmar Müürsepp \\ Maatalouden tutkimuskeskus ja Estonian Agricultural University, Eesti
}

\begin{abstract}
Alkionhalkaisun ja -siirron tehokkuutta selvitettiin kahdessa kokeessa siirtämällä halkaistuja alkioita tuoreina tai yön yli säilytyksen $\left(4^{\circ} \mathrm{C}\right)$ jälkeen. Alkionhalkaisut suoritettiin yksinkertaisella mikroveitsi-tekniikalla maatilalla. Kokeessa 1 siirrettiin 28 alkion puolikasta tuoreena vastaanottajahiehoihin, joista 20 tiinehtyi $(71,4 \%)$ tuottaen 19 vasikkaa. Kylmäsäilytyksen jälkeen (kokonaissäilytysaika 17-18 tuntia) 14 alkion puolikkaasta 12 arvioitiin siirtokelpoisiksi. Näistä yhdeksän siirrettiin vastaanottajahiehoihin, joista viisi tiinehtyi tuottaen neljä vasikkaa. Kokeessa 2 siirrettiin 21 alkion puolikasta vastaanottajahiehoihin. Näistä 12 tiinehtyi $(57,1 \%)$ poikien 10 vasikkaa. Kylmäsäilytyksen (kokonaissäilytysaika 22-24 tuntia) jälkeen siirrettiin 19 alkion puolikasta hiehoihin, joista viisi tiinehtyi. Näistä neljä poiki vasikan.
\end{abstract}

Tulosten perusteella voidaan todeta, että yksinkertaisella tekniikalla on mahdollista tuottaa halkaistuja alkioita, joiden elinkyky alkionsiirron jälkeen on samaa luokkaa kuin mitä yleensä saadaan käsittelemättömillä alkioilla. Kylmäsäilytyksen jälkeen halkaistujen alkioiden elinkyky heikkenee selvästi, mutta halkaistujen alkioiden kylmäsäilytys voi joissakin tilanteissa olla käytännöllistä. Toisen puolikkaan voi siirtää vastaanottajalle heti halkaisun jälkeen ja toisen seuraavana päivänä kylmäkuljetuksen jälkeen esimerkiksi toisella paikkakunnalla. Toinen menetelmän sovellutus on ottaa alkioista koepaloja, lähettää ne laboratorioon analysoitavaksi, ja valita diagnoosituloksen perusteella, mitkä kylmäsäilytetyistä alkioista siirretään seuraavana päivänä. 